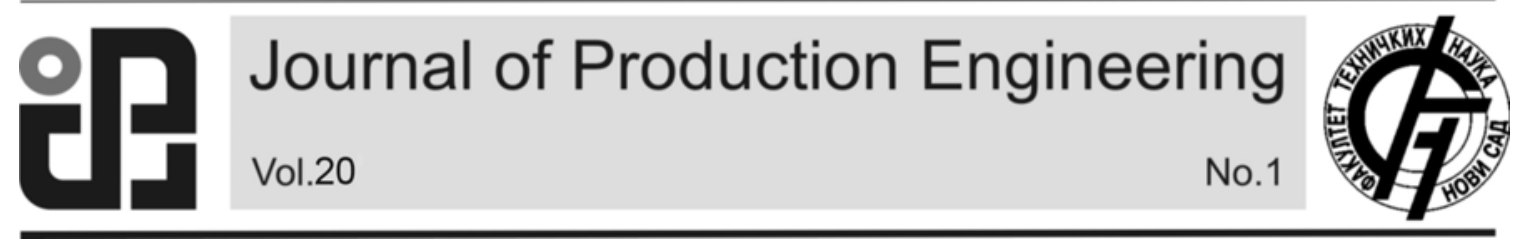

JPE (2017) Vol.20 (1)

Babič, M.

Preliminary Note

\title{
NEW METHOD FOR IMAGE ANALYSIS USING METHOD OF ESTIMATING FRACTAL DIMENSION OF 3D SPACE
}

Received: 07 April 2017 / Accepted: 19 May 2017

\begin{abstract}
In Mechanical Engineering we have many problems. Which materials use to build complex structure. How can we analyze materials? Have we good methods? How we prepare materials to have a long time a life. In this article we present a new method for image analysis using method of estimating fractal dimension of 3D space for robot laser hardened specimens. We analyze SEM picture of microstructure of robot laser hardened specimens with mathematical method. In this open problem we use graph theory and fractal geometry. We use methods of intelligent systems to make prediction in Mechanical Engineering. In imaging science, image processing is processing of images using mathematical operations by using any form of signal processing for which the input is an image, such as a photograph or video frame; the output of image processing may be either an image or a set of characteristics or parameters related to the image. Losely related to image processing are computer graphics and computer vision. In computer graphics, images are manually made from physical models of objects, environments, and lighting, instead of being acquired (via imaging devices such as cameras) from natural scenes, as in most animated movies.
\end{abstract}

Key words: image processing, intelligent system, fractal dimension, graph theory

Novi metod za analizu slike primenom metode procene fraktalne dimenzije u 3D prostoru. U mašinstva imamo mnogo problema. Koje materijale koristiti za izgradnju složene strukture. Kako možemo analizirati materijale? Da li su dobre metode? Kako ćemo pripremiti materijale da se dugo vremena koriste. U ovom članku ćemo predstaviti novu metodu za analizu slike metodom procene fraktalne dimenzije $3 D$ prostora pomoću robota za lasersko stvrdnjavanje uzoraka. Analiza SEM slike mikrostrukture stvrdnutih uzoraka pomoću lasera je pomoću matematičke metode. U ovom otvorenom problemu koristena je teoriju grafova i Fraktala geometrija. Korisćena je metoda inteligentnih sistema za predviđanje u mašinstvu. U nauci o slikama, obrada slike je obrada pomoću matematičke operacije koristeći bilo koji oblik obrade signala za koje je ulaz slika, kao što su fotografije ili video okviri; izlaz obrade slike može biti ili slika ili skup karakteristika ili parametara vezanih za slike. U blagoj vezi sa obradom slike su kompjuterske grafike i kompjuterska vizija. Kod kompjuterske grafike, slike su ručno izrađene od fizičkih modela objekata, okruženja, i osvetljenja, umesto da se stiče (preko uređaja za snimanje, kao što su kamere) od prirodnih scena, kao i u većini animiranih filmova.

Ključne reči: obrada slike, inteligentni sistem, fraktalna dimenzija, teorija grafova

\section{INTRODUCTION}

Image processing [1] is a method to convert an image into digital form and perform some operations on it, in order to get an enhanced image or to extract some useful information from it. It is a type of signal dispensation in which input is image, like video frame or photograph and output may be image or characteristics associated with that image. Usually Image Processing system includes treating images as two dimensional signals while applying already set signal processing methods to them. It is among rapidly growing technologies today, with its applications in various aspects of a business. Image Processing forms core research area within engineering and computer science disciplines too. Image processing is a method to perform some operations on an image, in order to get an enhanced image or to extract some useful information from it. It is a type of signal processing in which input is an image and output may be image or characteristics/features associated with that image. Nowadays, image processing is among rapidly growing technologies. It forms core research area within engineering and computer science disciplines too. Image processing basically includes the following three steps: Importing the image via image acquisition tools; Analysing and manipulating the image; Output in which result can be altered image or report that is based on image analysis. There are two types of methods used for image processing namely, analogue and digital image processing. Analogue image processing can be used for the hard copies like printouts and photographs. Image analysts use various fundamentals of interpretation while using these visual techniques. Digital image processing techniques help in manipulation of the digital images by using computers. The three general phases that all types of data have to undergo while using digital technique are pre-processing, enhancement, and display, information extraction. In this lecture we will talk about a few fundamental definitions such as image, digital image, and digital image processing. Different sources of digital images will be discussed and examples for each source will be provided. The 
continuum from image processing to computer vision will be covered in this lecture. Finally we will talk about new methot of image calculate with fractal dimension in $3 \mathrm{D}$ space with different types of image application in mechanical engineering, especialy in laser technology in hardening. Digital Processing techniques help in manipulation of the digital images by using computers. As raw data from imaging sensors from satellite platform contains deficiencies. To get over such flaws and to get originality of information, it has to undergo various phases of processing. The three general phases that all types of data have to undergo while using digital technique are Pre- processing, enhancement and display, information extraction.Fractals [2] is a new branch of mathematics and art. Perhaps this is the reason why most people recognize fractals only as pretty pictures useful as backgrounds on the computer screen or original postcard patterns.Process of robot laser hardening is presented in many articles [3-5]. Laser hardening offers customers an excellent alternative to induction and flame hardening. With laser precision and robot control, laser hardening can be applied to complex surfaces while achieving repeatable hardness and case depth. The aim of this study is to present a new method of image processing and it's aplication in calculate volume of 3D space with analize SEM images of robot laser hardened specimens using method of estimating calculating fractal dimansion of $3 \mathrm{D}$ objects.

\section{MATERIAL PREPARATION AND EXPERIMENTAL METHOD}

Firstly, we hardened tool steel with a robot laser cell. We changed two parameters, speed $\mathrm{v} \in[2,5] \mathrm{mm} / \mathrm{s}$ and temperature $\mathrm{T} \in[1000,1400]{ }^{\circ} \mathrm{C}$. Detailed characterization of their microstructure before and after surface modifications was conducted using a field emission scanning electron microscope (SEM), JEOL JSM-7600F. Also the SEM pictures were converted into binary images, from which we calculated the fractal dimension and into 3D graph, from which we calculate volume. For each $(x, y, z)$ we use only $z$ coordinate. Coordinate $\mathrm{z}$ have maximal value 255. Also, we calculate volume of robot laser hardened specimens with (1)

$$
\mathrm{V}=\frac{\mathrm{Z}_{1}+\mathrm{Z}_{2}+\ldots+\mathrm{Z}_{\mathrm{n} 4}}{n}
$$

for all $n$.

A random process is statistically evaluated using Hurst parameter $H$ or by determining the distribution function. Hurst parameter $H$ as self-similarity criteria can not be accurately calculated, but it can be only estimated. We use new method for calculating fractal dimension for 3D object [6]. For analyze results, we use one method of intelligent system, Genetic programming [7], neural network [8] and multiple regression [9]. In genetic programming we evolve a population of computer programs. That is, generation by generation, GP stochastically transforms populations of programs into new, hopefully better, populations of programs. GP, like nature, is a random process, and it can never guarantee results. In GP, programs are usually expressed as syntax trees rather than as lines of code. There are many problems where solutions cannot be directly cast as computerprograms. For example, in many design problems the solution is an artifact of some type: a bridge, a circuit, an antenna, a lens, etc. GP has been applied to problems of this kind by using a trick: the primitive set is set up so that the evolved programs construct solutions to the problem. This is analogous to the process by which an egg grows into a chicken.Genetic Algorithms are numerical optimization algorithms inspired by both natural selection and natural genetics (David 2001). It is a probabilistic search algorithm that iteratively transforms a set (called a population) of mathematical objects (typically fixed-length binary character strings), each with an associated fitness value, into a new population of offspring objects using the Darwinian principle of natural selection and using operations that are patterned after naturally occurring genetic operations, such as crossover (sexual recombination) and mutation (John 2007).
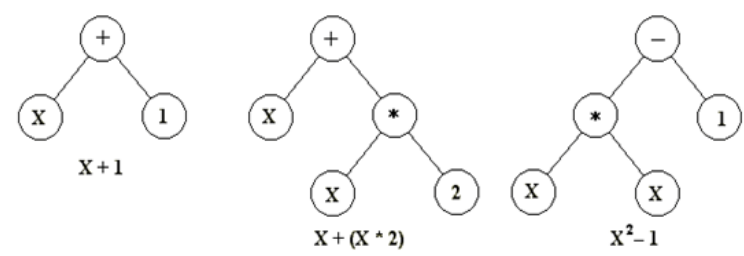

Fig. 1 - Model of genetic programming

Computer scientists have long been inspired by the human brain. In 1943, Warren S. McCulloch, a neuroscientist, and Walter Pitts, a logician, developed the first conceptual model of an artificial neural network [10]. In their paper, "A logical calculus of the ideas imminent in nervous activity," they describe the concept of a neuron, a single cell living in a network of cells that receives inputs, processes those inputs, and generates an output. Their work, and the work of many scientists and researchers that followed, was not meant to accurately describe how the biological brain works. Rather, an artificial neural network (which we will now simply refer to as a "neural network") was designed as a computational model based on the brain to solve certain kinds of problems. It's probably pretty obvious to you that there are problems that are incredibly simple for a computer to solve, but difficult for you. Take the square root of 964,324, for example. A quick line of code produces the value 982, a number Processing computed in less than a millisecond. There are, on the other hand, problems that are incredibly simple for you or me to solve, but not so easy for a computer. Show any toddler a picture of a kitten or puppy and they'll be able to tell you very quickly which one is which. Say hello and shake my hand one morning and you should be able to pick me out of a crowd of people the next day. But need a machine to perform one of these tasks? Scientists have already spent entire careers researching and implementing complex solutions. The most common application of neural networks in computing today is to perform one of these "easy-for-a-human, difficult-for-a-machine" tasks, often referred to as pattern recognition. 
Applications range from optical character recognition (turning printed or handwritten scans into digital text) to facial recognition. We don't have the time or need to use some of these more elaborate artificial intelligence algorithms here, but if you are interested in researching neural networks, I'd recommend the books Artificial Intelligence: A Modern Approach by Stuart J. Russell and Peter Norvig and AI for Game Developers by David M. Bourg and Glenn Seemann.

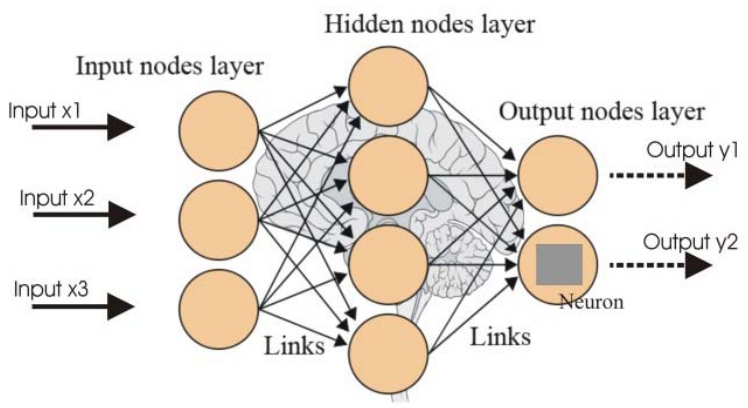

Fig. 2 - Model of neural network

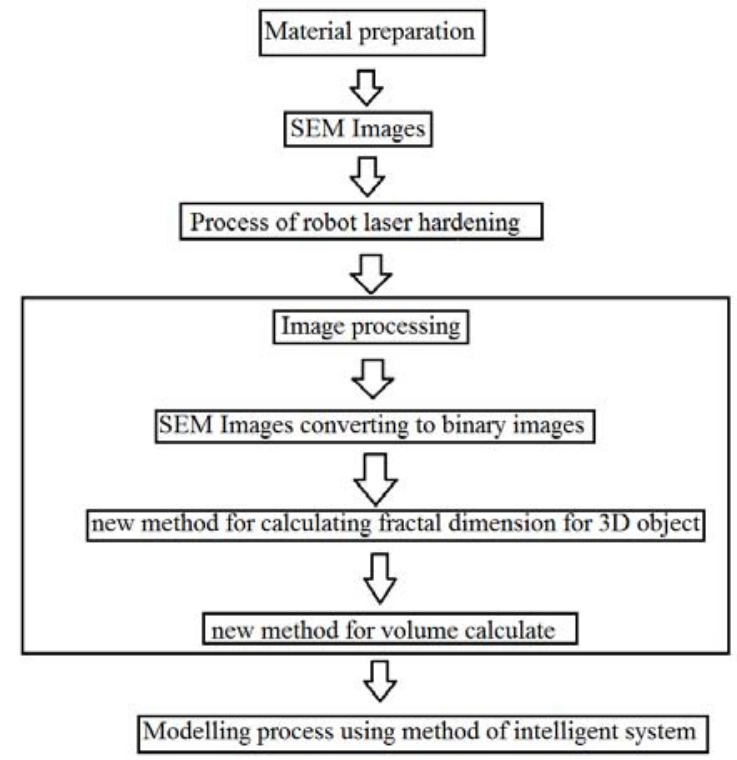

Fig. 3 - Model of intelligent system

Multiple linear regression analysis is used to examine the relationship between two or more independent variables and one dependent variable. The independent variables can be measured at any level (i.e., nominal, ordinal, interval, or ratio). However, nominal or ordinal-level IVs that have more than two values or categories (e.g., race) must be recoded prior to conducting the analysis because linear regression procedures can only handle interval or ratio-level IVs, and nominal or ordinal-level IVs with a maximum of two values (i.e., dichotomous). If there are $\mathrm{k}$ predictor variables, then the regression equation model is

$$
\mathrm{Y}=\beta_{0}+\mathrm{X}_{1} \beta_{1}+\cdots+\mathrm{X}_{\mathrm{n}} \beta_{\mathrm{n}}
$$

The $\mathrm{x}_{1}, \mathrm{x}_{2}, \ldots, \mathrm{x}_{\mathrm{k}}$ represent the $\mathrm{k}$ predictor variables. Those parameters are the same as before, $\beta_{0}$ is the $y$ intercept or constant, $\beta_{1}$ is the coefficient on the first predictor variable, $\beta_{2}$ is the coefficient on the second predictor variable, and so on. $\varepsilon$ is the error term or the residual that can't be explained by the model. Those parameters are estimated by $b_{0}, b_{1}, b_{2}, \ldots, b_{n}$.

This gives us a regression equation used for prediction of

$$
\mathrm{Y}=\beta_{0}+\mathrm{X}_{1} \beta_{1}+\cdots+\mathrm{X}_{\mathrm{n}} \beta_{\mathrm{n}}
$$

Basically, everything we did with simple linear regression will just be extended to involve $\mathrm{k}$ predictor variables instead of just one.

\section{RESULTS AND DISCUSSION}

In Table 1, the parameters which impact on SEM image of hardened materials. We mark specimens from P1 to P21. Parameter $\mathrm{X}_{1}$ presents the parameter of temperature in degree of Celsius $[\mathrm{C}], \mathrm{X}_{2}$ presents the speed of hardening $[\mathrm{mm} / \mathrm{s}], X_{3}$ presents fractal dimension in $3 \mathrm{D}$ space and $\mathrm{X}_{4}$ presents basic volume of laser-hardened robot specimens in 3D space. The last parameter $\mathrm{Y}$ is the measured volume of laserhardened robot specimens. Table 2 presents experimental and prediction data regarding the volume of laser hardened robot specimens. In Table 2 present symbol $\mathrm{S}$ name of specimens, E experimental data, NM1 prediction with neural network with $30 \%$ learn set, NN2 prediction with neural network with 50\% learn set, NN3 prediction with neural network with method one live out, $\mathrm{R}$ prediction with regression, GP prediction with genetic programming. In Table 1, we can see that specimen P16 has the largest volume; 77,7. The measured and predicted volume of robot laser hardened specimens is shown in the graph in Fig. 4. The genetic programming model is presented under Table 2. Under model of genetic programming is presented model of regression. The genetic programming model presents a $20,79 \%$ deviation from the measured data, which is less than the regression model, which presents a $35,11 \%$ deviation. The best neural network NN3 present 31,48\% deviation from the measured data.

\begin{tabular}{|c|c|c|c|c|c|}
\hline $\mathrm{S}$ & $\mathrm{X}_{1}$ & $\mathrm{X}_{2}$ & $\mathrm{X}_{3}$ & $\mathrm{X}_{4}$ & $\mathrm{Y}$ \\
\hline P1 & 1000,0 & 2,0 & 2,304 & 8,3 & 28,0 \\
\hline P2 & 1000,0 & 3,0 & 2,264 & 8,3 & 20,6 \\
\hline P3 & 1000,0 & 4,0 & 2,258 & 8,3 & 25,4 \\
\hline P4 & 1000,0 & 5,0 & 2,341 & 8,3 & 22,5 \\
\hline P5 & 1400,0 & 2,0 & 2,222 & 8,3 & 22,9 \\
\hline P6 & 1400,0 & 3,0 & 2,388 & 8,3 & 19,3 \\
\hline P7 & 1400,0 & 4,0 & 2,25 & 8,3 & 13,2 \\
\hline P8 & 1400,0 & 5,0 & 2,286 & 8,3 & 21,0 \\
\hline P9 & 1000,0 & 2,0 & 2,178 & 28,0 & 24,0 \\
\hline P10 & 1000,0 & 3,0 & 2,183 & 20,6 & 27,5 \\
\hline P11 & 1000,0 & 4,0 & 2,408 & 25,4 & 28,7 \\
\hline P12 & 1000,0 & 5,0 & 2,210 & 22,5 & 23,7 \\
\hline P13 & 1400,0 & 2,0 & 2,257 & 22,9 & 26,3 \\
\hline P14 & 1400,0 & 3,0 & 2,265 & 19,3 & 22,1 \\
\hline P15 & 1400,0 & 4,0 & 2,433 & 132 & 20,3 \\
\hline P16 & 1400,0 & 5,0 & 2,289 & 21,0 & 77,7 \\
\hline P17 & 800,0 & 0,0 & 2,232 & 8,3 & 15,3 \\
\hline P18 & 1400,0 & 0,0 & 2,235 & 8,3 & 31,8 \\
\hline P19 & 2000,0 & 0,0 & 2,261 & 8,3 & 36,9 \\
\hline P20 & 950,0 & 0,0 & 2,282 & 8,3 & 70,8 \\
\hline P21 & 850,0 & 0,0 & 2,319 & 8,3 & 43,9 \\
\hline
\end{tabular}

Table 1. Parameters of images of hardened specimens 


\begin{tabular}{|c|c|c|c|c|c|c|}
\hline S & E & NN1 & NN2 & NN3 & R & GP \\
\hline P1 & 28 & 28,3 & 28,33 & 27,77 & 26,6 & 21,29 \\
\hline P2 & 20 & 19,8 & 19,92 & 21,47 & 23,4 & 19,84 \\
\hline P3 & 25 & 25,4 & 25,27 & 24,79 & 21,2 & 21,87 \\
\hline P4 & 22 & 22,7 & 23,12 & 22,63 & 21,5 & 22,86 \\
\hline P5 & 22 & 22,7 & 22,80 & 22,71 & 28,3 & 21,57 \\
\hline P6 & 19 & 19,1 & 19,06 & 19,43 & 30,8 & 21,04 \\
\hline P7 & 13 & 14,6 & 14,70 & 12,72 & 25,0 & 13,47 \\
\hline P8 & 21 & 20,1 & 20,01 & 20,86 & 23,9 & 22,71 \\
\hline P9 & 24 & 5,57 & 24,07 & 24,09 & 32,8 & 24,42 \\
\hline P10 & 27 & 6,48 & 27,51 & 27,65 & 27,2 & 22,86 \\
\hline P11 & 28 & 6,85 & 28,73 & 28,62 & 33,8 & 28,49 \\
\hline P12 & 23 & 10,8 & 30,84 & 80,26 & 24,8 & 28,06 \\
\hline P13 & 26 & 8,71 & 49,43 & 24,72 & 36,4 & 26,38 \\
\hline P14 & 22 & 7,08 & 42,85 & 23,50 & 32,8 & 25,51 \\
\hline P15 & 20 & 10,6 & 18,83 & 20,21 & 32,5 & 20,20 \\
\hline P16 & 77 & 6,59 & 35,92 & 77,47 & 30,2 & 30,94 \\
\hline P17 & 15 & 48,1 & 49,92 & 15,22 & 26,7 & 13,72 \\
\hline P18 & 31 & 41,2 & 30,49 & 31,81 & 32,7 & 30,94 \\
\hline P19 & 36 & 30,6 & 17,95 & 36,79 & 39,4 & 36,90 \\
\hline P20 & 70 & 46,0 & 48,08 & 70,76 & 29,5 & 34,35 \\
\hline P21 & 43 & 44,2 & 56,22 & 43,85 & 29,6 & 43,98 \\
\hline
\end{tabular}

A statistically significant relationship was found between volume, the parameters of the robot laser cell and image analysis with new method of fractal geometry calculate for object in 3D space. In addition, image analysis of SEM images of robot laser hardened specimens is an interesting approach. Specimen P16 has the most volume after robot laser hardening, that is $77,7 \%$. Parameter X3 (fractal dimension) has most impact on Regression model. Parameter X4 (base volume) has most impact on genetic programing. We use method of intelligent systems; genetic programming, neural network and multiple regression to predict volume of robot laser hardened specimens. We show that the genetic programming give us the best predicted results. The neural network model is better than the regression model.

Model of regression

$$
\begin{aligned}
Y=47,35891887 & +0,0098937467 \times X_{1} \\
& -2,03904329 \times X_{2} \\
& +27,81672014 \times X_{3} \\
& +0,0491686011 \times X_{4}
\end{aligned}
$$

Table 2: Experimental and prediction data

Model of genetic programming

$\mathrm{Y}$

$=0,0162358$

$$
\begin{aligned}
& \times\left(-5,51153+X_{1}+6 \times X_{4}-\frac{X_{1}}{\frac{-2 \times X_{1}}{X_{4}}+X_{4}}-\frac{X_{1}}{\frac{-5 \times X_{1}}{2 \times X_{4}}+X_{4}}-\frac{2 \times\left(-11,0231+X_{1}\right)}{-0,181438+2 \times X_{4}}\right. \\
& -\frac{2 \times\left(-5,51153+X_{1}\right)}{-0,181438 \times X_{1}+2 \times X_{4}}-\frac{-16,5346+X_{1}+3 \times X_{4}-\frac{X_{1}+X_{2}}{X_{2}}+\frac{X_{1}}{X_{4}}}{X_{2}} \\
& -\frac{2 \times\left(-5,51153+1,18144 \times X_{1}+X_{4}\right)}{2 \times X_{4}-0,181438 \times\left(X_{1}+X_{4}-11,0231\right)}-\frac{-11,0231+X_{1}-\frac{X_{1}}{X_{2}}-\frac{2 \times X_{1}}{X_{4}}-4 \times X_{4}-\frac{X_{1}+X_{3}+X_{4}}{X_{2}}}{X_{2}} \\
& \left.-\frac{\left.-5,51153+X_{2}+4 \times X_{4}-\frac{-0,818562 \times X_{1}+X_{4}}{X_{2}}+\frac{X_{1}+\frac{-5,51153+0,818562 \times X_{1}+X_{4}}{X_{2}}}{X_{4}}\right)}{1}\right)
\end{aligned}
$$

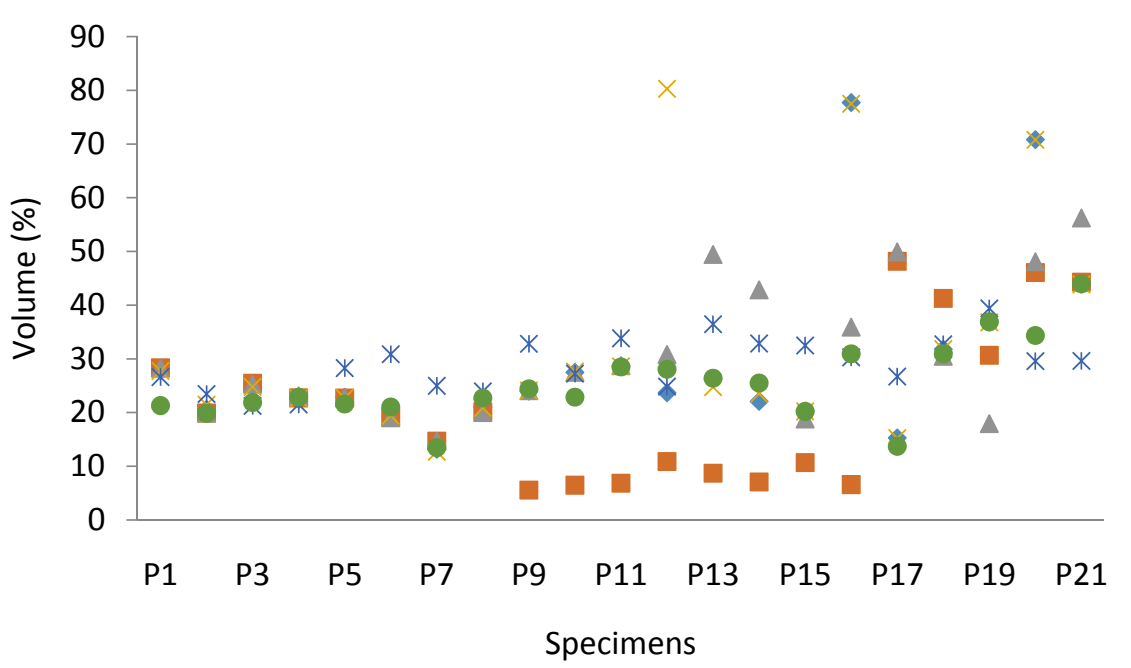

Fig. 4. The measured and predicted volume of robot laser hardened specimens 


\section{CONCLUSIONS}

In this article we present a new method for image analysis of robot laser hardened materials, which have many applications in Mechanical Engineering, like in construction of bridges, railways, skyscrapers. The SEM pictures were converted into $3 \mathrm{D}$ graph, from which we calculate volume. The paper presents the use of method of intelligent system namely genetic programming, neural network and multiple regression to predict volume of hardened specimens. We use method for describe complexity, estimating fractal dimension in 3D space. In the future, we want to explore new method for image processing in 3D space as a function of the parameters of a robot cell for laser hardening for pinned robot laser hardening: laser parameters such as power, energy density, focal distance, energy density in the focus, focal position, the shape of the laser flash, flash frequency, temperature and speed of hardening. We are interested in new method for image processing in SEM pictures of:

- Two-beam laser robot hardening (where the laser beam is divided into two parts) specimens

- Areas of overlap (where the laser beam covers the already hardened area) specimens

- Robot laser hardening at different angles (where the angles change depending on the $x$ - and $y$-axes) specimens.

\section{References}

[1] Rafael C. Gonzalez; Richard E. Woods (2008). Digital Image Processing. Prentice Hall. pp. 1-3. ISBN 978-0-13-168728-8.

[2] Mandelbrot, B. B. The fractal geometry of nature. New York: W. H. Freeman, 1982:93.

[3] J. Grum, P. Žerovnik, R. Šturm: Measurement and Analysis of Residual Stresses after Laser Hardening and Laser Surface Melt Hardening on Flat Specimens; Proceedings of the Conference "Quenching '96", Ohio, Cleveland, 1996.

[4] BABIČ, Matej, MILFELNER, Matjaž, BELIČ, Igor, KOKOL, Peter. Problems associated with a robot laser cell used for hardening = Problematika robotskega laserskega kaljenja. Materiali in tehnologije, ISSN 1580-2949. [Tiskana izd.], jan.feb. 2013, letn. 47, št. 1, str. 37-41.

[5] BABIČ, Matej, BALIČ, Jože, MILFELNER, Matjaž, BELIČ, Igor, KOKOL, Peter, ZORMAN, Milan, PANJAN, Peter. Robot laser hardening and the problem of overlapping laser beam. Advances in production engineering \& management, ISSN 1854-6250, 2013, vol. 8, no. 1, str. 25-32.

[6] BABIČ, Matej, KOKOL, Peter, GUID, Nikola, PANJAN, Peter. A new method for estimating the Hurst exponent $\mathrm{H}$ for $3 \mathrm{D}$ objects. Materiali in tehnologije, ISSN 1580-2949, 2014, letn. 48, št. 2, str. 203-208. http://mit.imt.si/Revija/.

[7] Koza, John (1992). Genetic Programming: On the Programming of Computers by Means of Natural Selection. Cambridge, MA: MIT Press. ISBN 9780262111706.

[8] Graves, Alex; and Schmidhuber, Jürgen; Offline Handwriting Recognition with Multidimensional Recurrent Neural Networks, in Bengio, Yoshua; Schuurmans, Dale; Lafferty, John; Williams, Chris K. I.; and Culotta, Aron (eds.), Advances in Neural Information Processing Systems 22 (NIPS'22), December 7th-10th, 2009, Vancouver, BC, Neural Information Processing Systems (NIPS) Foundation, 2009, pp. 545-552.

[9] Box, G. E. P. (1954). "Some Theorems on Quadratic Forms Applied in the Study of Analysis of Variance Problems, I. Effect of Inequality of Variance in the One-Way Classification". The Annals of Mathematical Statistics 25 (2): 290. doi:10.1214/aoms/1177728786.

[10] Daniel Shiffman. The Nature of Code. http://dep.fie.umich.mx/ garibaldi/data/uploads/gr aficacion/nature_of_code005_shiffman_12.4.12.pdf

Author: Dr. Matej Babič, Bs. M.

Jožef Stefan Institute, Ljubljana, Slovenia

E-mail: babicster@gmail.com 